\title{
Meningkatkan Keaktifan Dan Hasil Belajar Peserta Didik Melalui Model PBL Pada Materi Persamaan Garis Lurus
}

\author{
Pendy Santoso
}

\author{
SMP Lentera Kasih bali, Indonesia \\ Email:pendyheribertus@gmail.com
}

\begin{abstract}
Abstrak
Penelitian ini dilatarbelakangi oleh kurangnya keaktifan dan hasil belajar peserta didik yang rendah dalam pembelajaran matematika. Untuk meningkatkan keaktifan dan hasil belajar peserta didik, peneliti menggunakan model Problem Based Learning. Tujuan penelitian ini untuk meningkatkan keaktifan dan hasil belajar peserta didik dengan menggunakan model pembelajaran problem based learning. Penelitian ini merupakan penelitian tindakan kelas, dengan populasi adalah peserta didik kelas VIII SMP Lentera Kasih Bali Tahun Ajaran 2020/2021. Teknik pengumpulan data untuk keaktifan peserta didik adalah observasi dan pengisian angket keaktifan, sedangkan untuk pengumpulan data hasil belajar menggunakan tes. Berdasarkan hasil penelitian, dapat disimpulkan bahwa: (1) Keaktifan belajar peserta didik meningkat dalam mengikuti pembelajaran dengan model problem based learning (nilai rata-rata keaktifan peserta didik berdasarkan observasi untuk siklus 1 , siklus 2 , dan siklus 3 berturut-turut adalah 73, 78, dan 82, sedangkan berdasarkan angket keaktifan berturut-turut adalah 69, 78, dan 82). (2) Hasil belajar peserta didik meningkat dalam mengikuti kegiatan pembelajaran dengan model problem based learning pada materi persamaan garis lurus (nilai rata-rata hasil belajar peserta didik untuk siklus 1 , siklus 2 , dan siklus 3 berturut-turut adalah 44,$8 ; 70,7$; dan 79,6 )
\end{abstract}

Katakunci: problem based learning, keaktifan peserta didik, hasil belajar

\begin{abstract}
This research is done based on the lack of participation and low student achievement in mathematical studies. To improve participation and student achievement, the researcher used the Problem Based Learning model. The objective of this research is to improve students' participation and performance using the Problem Based Learning model. This research is a class research with Grade 8 students of SMP Lentera Kasih Bali Academic year 2020/2021 as sample. The data collection technique in measuring students participation is observation and survey, while the data collection for measuring academic results is taken from students' tests. Based on this research, we can conclude that: (1) Students' participation in learning improved when the Problem Based Learning model is used (the average mark for students' participation based on consecutive observations for cycle 1, cycle 2 and cycle 3 is 73, 78 and 82, meanwhile based on consecutive students' participation survey is 69, 78 and 82). (2) Students' participation results improved on the persamaan garis lurus topic when the problem learning method is used (the average students' results for cycle 1, cycle 2 and cycle 3 consecutively is 44.8, 70.7 and 79.6).
\end{abstract}

Keywords: problem based learning, students' participation, academic result 


\section{PENDAHULUAN}

Matematika merupakan salah satu mata pelajaran yang memberikan kontribusi positif akan tercapainya generasi yang mampu berpikir kritis, kreatif, kolaboratif, komunikatif. Matematika merupakan mata pelajaran yang bersifat abstrak, yang menuntut guru untuk dapat mengupayakan metode yang tepat dan sesuai dengan tingkat perkembangan peserta didik. Untuk itu, diperlukan model dan media pembelajaran yang dapat membantu peserta didik untuk dapat mencapai kompetensi dan indikator pencapaian kompetensi.

Berdasarkan pengalaman selama proses pembelajaran daring, proses pembelajaran matematika yang dilakukan di SMP Lentera Kasih adalah pembelajaran yang berpusat pada guru dengan metode ceramah. Dengan metode ceramah yang dilakukan oleh guru, peserta didik masih belum terlibat aktif dalam kegiatan pembelajaran. Dalam proses pembelajaran matematika secara daring yang telah dilakukan, peserta didik masih lemah dalam pemahaman konsep materi yang dipelajari, hal ini yang menyebabkan hasil belajar peserta didik rendah jika dilihat dari hasil rata-rata tengah semester 1, yaitu 66,4. Oleh karena itu, keaktifan peserta didik dalam mengikuti kegiatan pembelajaran dan hasil belajar peserta didik perlu ditingkatkan.

Keaktifan peserta didik dalam kegiatan belajar adalah untuk mengkontruksi pengetahuan mereka sendiri. Keaktifan dapat membangun pemahaman atas persoalan atau segala sesuatu yang mereka hadapi dalam proses pembelajaran. Menurut Nana Sudjana (2004: 61), peserta didik dikatakan aktif dalam pembelajaran bila terdapat ciri-ciri sebagai berikut: (1) turut serta dalam melaksanakan tugas belajarnya, (2) terlibat dalam pemecahan masalah, (3) bertanya kepada peserta didik lain atau guru apabila tidak memahami pesoalan yang dihadapinya, (4) berusaha mencari berbagai informasi yang diperlukan untuk pemecahan masalah, melaksanakan diskusi kelompok sesuai dengan petunjuk guru, (6) menilai kemampuan dirinya dan hasil-hasil yang diperolehnya, (7) melatih diri dalam memecahkan soal atau masalah sejenis, (8) kesempatan menggunakan atau menerapkan apa yang diperoleh dalam menyelesaikan tugas atau persoalan yang dihadapinya.

Keaktifan dapat ditingkatkan dan diperbaiki dalam keterlibatan peserta 
didik pada saat belajar (Suryanti, Sutaji, \& Arifani, 2019). Hal tersebut seperti dijelaskan oleh Moh. Uzer Usman (2009: 26-27) cara untuk memperbaiki keterlibatan peserta didik diantaranya yaitu abadikan waktu yang lebih banyak untuk kegiatan belajar mengajar, tingkatkan partisipasi peserta didik secara efektif dalam kegiatan belajar mengajar, serta berikanlah pengajaran yang jelas dan tepat sesuai dengan tujuan mengajar yang akan dicapai.

Hasil belajar menggambarkan kemampuan peserta didik dalam mempelajari sesuatu. Hal ini sesuai dengan pendapat Nana Sudjana (1989:50) yang menyebutkan bahwa: "Hasil belajar adalah kemampuan yang dimiliki atau dikuasai peserta didik setelah menempuh proses belajar". Hasil belajar mencakup kemampuan kognitif (intelektual), afektif (sikap), dan kemampuan psikomotorik (bertindak). Menurut Sardiman AM (dalam Siti Umamik, 2007:11-13), salah satu factor yang mempengaruhi hasil belajar adalah keaktifan peserta didik.

Salah satu model pembelajaran yang dapat diterapkan untuk meningkatkan keaktifan dan hasil belajar peserta didik adalah model pembelajaran problem based learning. Model pembelajaran problem based learning merupakan model pembelajaran yang mendorong peserta didik lebih aktif, kreatif, mandiri dan tanggung jawab dalam belajar. Sehingga dengan siswa terlibat aktif dalam pembelajaran, siswa benar-benar mengalami proses belajar, sehingga siswa mampu memahami konsep dengan baik (Suryanti, Khikmiyah, Zawawi, \& Fauziyah, 2014), yang pada akhirnya akan meningkatkan hasil belajar. Melalui model pembelajaran problem based learning, diharapkan dapat meningkatkan keaktifan dan hasil belajar peserta didik pada materi persamaan garis lurus.

Prinsip utama pembelajaran berbasis masalah adalah penggunaan masalah nyata sebagai sarana bagi peserta didik untuk mengembangkan keterampilan berpikir kritis, keterampilan menyelesaikan masalah dan serta mengembangkan pengetahuan. Pembelajaran berbasis masalah dapat dilakukan secara individual maupun kelompok. Jika masalah diselesaikan secara individual diharapkan akan terbentuk sikap mandiri, sementara jika diselesaikan secara berkelompok diharapkan antarpeserta didik dapat saling sharing/berbagi pengetahuan.

\section{METODE}


Penelitian ini merupakan penelitian tindakan kelas yang dilakukan di SMP Lentera Kasih Bali. Penelitian dilakukan selama bulan Oktober-November 2020 dengan 23 peserta didik kelas VIII sebagai subjek penelitian. Kegiatan penelitian ini dilaksanakan selama tiga siklus dengan tahapan perencanaan, pelaksanaan/ tindakan, observasi/pengamatan dan refleksi. Materi yang dipilih adalah “persamaan garis lurus”.

Tabel 1. Aspek Keaktifan dan Indikatornya

\begin{tabular}{|c|c|c|}
\hline No & As & \\
\hline 1. & $\begin{array}{l}\text { Interaksi } \\
\text { peserta } \\
\text { didik } \\
\text { dengan } \\
\text { guru }\end{array}$ & $\begin{array}{ll}\text { - } & \text { Bertanya kepada } \\
\text { guru } \\
\text { - } \\
\text { Menjawab } \\
\text { pertanyaan guru } \\
\text { - } \text { Mendengarkan } \\
\text { penjelasan/ } \\
\text { informasi guru }\end{array}$ \\
\hline 2. & $\begin{array}{l}\text { Aktifitas } \\
\text { peserta } \\
\text { didik } \\
\text { dalam } \\
\text { kelompok }\end{array}$ & 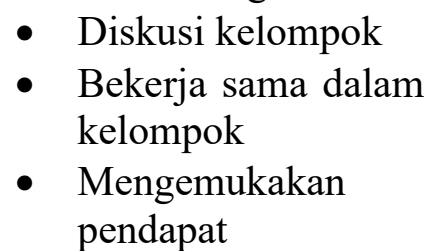 \\
\hline 3. & $\begin{array}{l}\text { Aktifitas } \\
\text { peserta } \\
\text { didik } \\
\text { dalam } \\
\text { presentasi }\end{array}$ & 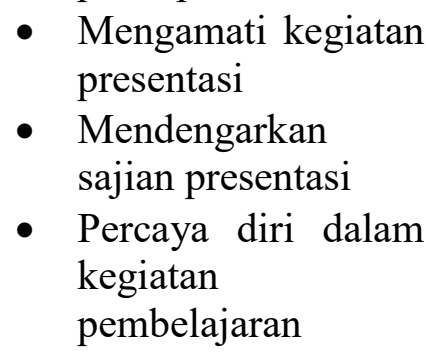 \\
\hline 4. & $\begin{array}{l}\text { Menyeles } \\
\text { aikan soal } \\
\text { dan tugas }\end{array}$ & $\begin{array}{ll}\text { - } & \text { Membu } \\
\text { - } & \text { Menuli } \\
& \text { LKPD }\end{array}$ \\
\hline
\end{tabular}

Table 2. Aspek Angket Keaktifan dan Indikatornya

\begin{tabular}{|c|c|c|}
\hline No & spek & 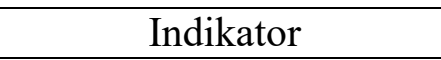 \\
\hline 1. & Motivasi & 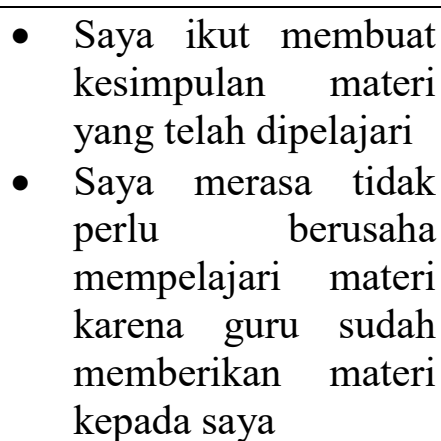 \\
\hline 2. & $\begin{array}{l}\text { Interaksi } \\
\text { peserta } \\
\text { didik } \\
\text { dengan } \\
\text { guru }\end{array}$ & $\begin{array}{l}\text { - Saya mendengarkan } \\
\text { dan mempeehatikan } \\
\text { guru saat } \\
\text { menjelaskan materi } \\
\text { - Saya tidak akan } \\
\text { bertanya kepada guru } \\
\text { walaupun tidak } \\
\text { paham terhadapa } \\
\text { materi yang } \\
\text { disampaikan } \\
\text { - Saya tidak berani } \\
\text { menyampaikan } \\
\text { pendapat ketika } \\
\text { diminta guru untuk } \\
\text { menyampaikan } \\
\text { pendapat saya }\end{array}$ \\
\hline 3. & $\begin{array}{l}\text { Aktifitas } \\
\text { peserta } \\
\text { didik } \\
\text { dalam } \\
\text { kelompo } \\
\text { k }\end{array}$ & $\begin{array}{l}\text { - Saya bertanya kepada } \\
\text { teman satu kelompok } \\
\text { jika tidak/belum } \\
\text { paham dengan materi } \\
\text { yang dipelajari } \\
\text { - Saya tidak berani } \\
\text { menyampaikan } \\
\text { pendapat saya ketika } \\
\text { ditanya oleh teman } \\
\text { satu kelompok saya } \\
\text { - Saya ikut serta dalam } \\
\text { diskusi kelompok }\end{array}$ \\
\hline 4. & $\begin{array}{l}\text { Aktifitas } \\
\text { peserta } \\
\text { didik } \\
\text { dalam } \\
\text { presentas } \\
\text { i }\end{array}$ & $\begin{array}{l}\text { - Saya bekerja sama } \\
\text { dengan teman satu } \\
\text { kelompok dalam } \\
\text { diskusi kelompok } \\
\text { - Saya menghargai } \\
\text { setiap pendapat } \\
\text { teman yang berbeda }\end{array}$ \\
\hline
\end{tabular}


- Saya ik ut mempresentasikan hasil kerja kelompok

\section{HASIL DAN PEMBAHASAN}

\section{Siklus 1}

Perencanaan I

Tahap perencanaan yang dilakukan pada siklus 1, yaitu menyusun perangkat pembelajaran yang akan digunakan dengan mempertimbangkan temuan, yaitu kurangnya keaktifan dan hasil belajar peserta didik berdasarkan nilai rata-rata tengah semester 1. Pembelajaran pada siklus 1 dilakukan dengan diskusi kelompok. Selain menyusun perangkat pembelajaran, dilakukan juga pembagian kelompok yang heterogen sesuai dengan nilai tengah semester 1 , kemudian menyiapkan lembar observasi, lembar angket peserta didik dan lembar soal evaluasi.

Pelaksanaan I

Tahap pelaksanaan I dilakukan dalam satu pertemuan, yaitu hari Kamis, 22 Oktober 2020. Pada tahap apersepsi, guru menampilkan masalah dalam kontekstual terkait persamaan garis lurus dengan menggunakan media powerpoint. Dari permasalahan tersebut, peserta didik berdiskusi secara kelompok untuk menemukan penyelesaian dan penggunaan kemiringan garis lurus pada masalah kontekstual, dan menemukan konsep tentang kemiringan/gradien garis lurus dan menentukan persamaan garis lurus. Setelah berdiskusi secara kelompok, perwakilan dari kelompok mempresentasikan hasil diskusi kelompok mereka. Setiap anggota kelompok yang presentasi bertanggung jawab untuk dapat menjawab atau menjelaskan jika ada pertanyaan dari kelompok lain. Kelompok yang tidak presentasi memperhatikan dan memberikan tanggapan terkait penyelesaian yang dipresentasikan.

Evaluasi pembelajaran dilakukan di luar jam pelajaran, dan dikerjakan melalui google form.

Pengamatan dan Evaluasi I

Pengamatan terhadap keaktifan peserta didik dalam mengikuti kegiatan pembelajaran dilakukan selama proses pembelajaran berlangsung. Dari empat kelompok diskusi, sebagian besar peserta didik masih merasa canggung karena baru pertama kali melakukan kegiatan diskusi kelompok secara daring. Peserta didik masih cenderung menyelesaikan LKPD secara individu, dan hanya menyampaikan penyelesaian akhir pada anggota kelompok yang lain. Ada satu kelompok yang benar-benar 
aktif dalam melakukan diskusi kelompok.

Setelah dilakukan perhitungan hasil observasi, secara keseluruhan keaktifan peserta didik selama proses pembelajaran selama proses pembelajaran berlangsung termasuk dalam kualifikasi sedang dengan skor rata-rata 73. Sedangkan berdasarkan hasil angket, keaktifan peserta didik termasuk dalam kualifikasi sedang Degnan skor rata-rata 69. Perhitangan hasil belajar peserta didik diperoleh nilai rata-rata 44,8 dimana terdapat 10 peserta didik yang tuntas, sedangkan 13 peserta didik tidak tuntas.

Analisis dan Refleksi I

Berdasarkan hasil pengamatan yang diperoleh selama pelaksanaan tindakan dan evaluasi dari siklus 1 , ada beberapa hal penting yang perlu diperhatikan dan diperbaiki untuk rencana tindakan pada siklus berikutnya. Keaktifan peserta didik dalam mengikuti kegiatan pembelajaran belum begitu terlihat, terutama pada saat melakukan diskusi kelompok. Hal ini disebabkan karena peserta didik belum terbiasa dalam melakukan kegiatan diskusi kelompok secara daring. Terlihat peserta didik belum dapat dengan maksimal menyampaikan pendapatnya dalam diskusi kelompok. Penyebab lainnya adalah kurangnya motivasi yang diberikan oleh guru kepada siswa pada saat pembelajaran dan juga kurangnya perhatian siswa dalam mendengarkan penjelasan dan masukan dari guru. Selain itu peserta didik tidak membaca dengan cermat petunjuk pada LKPD, sehingga menyebabkan peserta didik kurang memahami permasalahan yang diberikan.

\section{Siklus II}

Perencaan II

Tahap perencanaan yang dilakukan pada siklus 1, yaitu menyusun perangkat pembelajaran berdasarkan hasil refleksi pada siklus 1 , dengan melengkapi hal-hal penting yang perlu ditambahkan dan diperhatikan.

Pelaksanaan II

Tahap pelaksanaan II dilakukan dalam satu pertemuan, yaitu hari Senin, 2 November 2020. Pada tahap apersepsi, guru menampilkan masalah dalam kontekstual terkait garis yang saling sejajar dan saling tegak lurus, serta hubungan gradien dan persamaan garis lurus dengan menggunakan media powerpoint. Dari permasalahan tersebut, peserta didik berdiskusi secara kelompok untuk menemukan penyelesaian dan menemukan konsep tentang gradien dua garis yang saling sejajar dan dua garis saling tegak lurus, 
serta menentukan persamaan garis yang sejajar dengan garis lain atau tegak lurus dengan garis yang lain.

Setelah berdiskusi secara kelompok, perwakilan dari kelompok mempresentasikan hasil diskusi kelompok mereka. Setiap anggota kelompok yang presentasi bertanggung jawab untuk dapat menjawab atau menjelaskan jika ada pertanyaan dari kelompok lain. Kelompok yang tidak presentasi memperhatikan dan memberikan tanggapan terkait penyelesaian yang dipresentasikan.

Evaluasi pembelajaran dilakukan di luar jam pelajaran, dan dikerjakan melalui google form.

Pengamatan dan Evaluasi II

Pengamatan terhadap keaktifan peserta didik dalam mengikuti kegiatan pembelajaran dilakukan selama proses pembelajaran berlangsung. Peserta didik sudah mulai terbiasa untuk berdiskusi kelompok secara daring dengan menggunakan google meet. Setiap kelompok membagikan LKPD dalam bentuk google docs, yang bisa diisi oleh setiap anggota kelompok. Dalam diskusi kelompok, setiap anggota kelompok menyampaikan pendapatnya secara langsung maupun dengan menuliskan pendapatnya pada google docs yang telah dibagikan.
Diskusi kelompok pada siklus 2 menjadi lebih aktif dan efektif.

Refleksi II

Setelah dilakukan perhitungan hasil observasi, secara keseluruhan keaktifan peserta didik selama proses pembelajaran siklus 2 mengalami kenaikan jika dibandingkan dengan siklus yang pertama, dimana skor ratarata siklus 1 adalah 73 dan di siklus yang kedua menjadi 78, dengan kualifikasi/kategori keaktifan di siklus 2 adalah kategori tinggi. Sedangkan berdasarkan hasil angket, keaktifan peserta didik jika mengalami kenaikan dari siklus 1, dimana skor rata-rata siklus 1 adalah 69 dan di siklus 2 menjadi 78, dengan kualifikasi/kategori tinggi. Sedangkan untuk hasil belajar peserta didik, diperoleh nilai rata-rata 70,8 dimana terdapat 12 peserta didik yang tuntas, sedangkan 11 peserta didik tidak tuntas. Nilai rata-rata hasil belajar peserta didik sudah mengalami peningkatan dibandingkan siklus 1 .

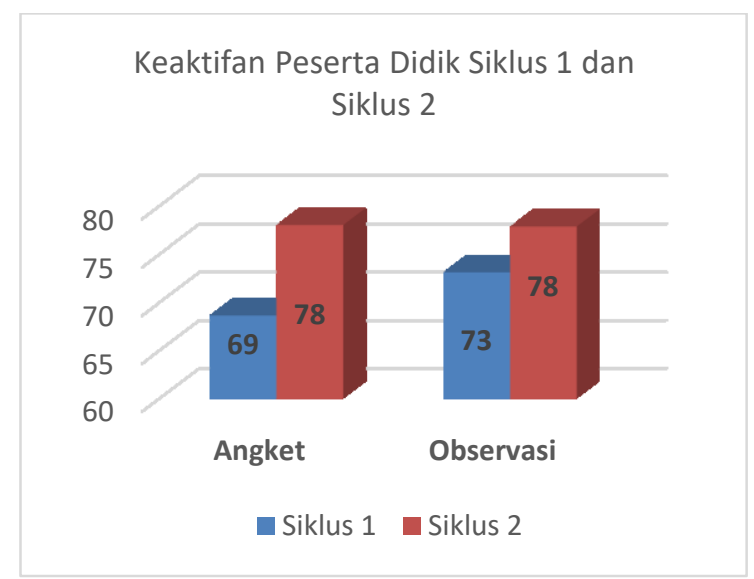


Gambar 1. Peningkatan Keaktifan

Peserta Didik Siklus 1 ke Siklus 2

Hasil Evaluasi Belajar Siklus 1 ke Siklus 2

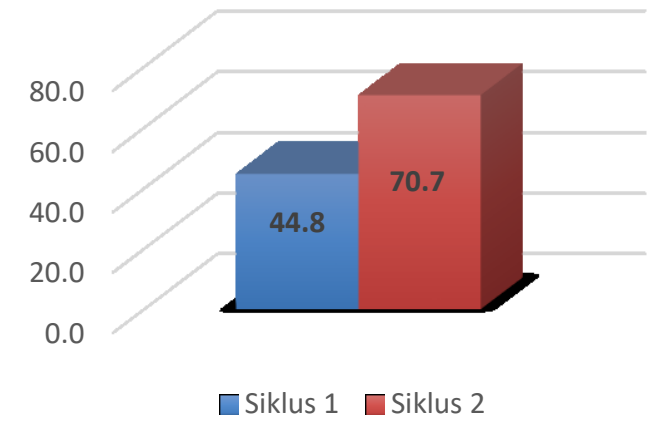

Gambar 2. Peningkatan Hasil Belajar

Peserta Didik Siklus 1 ke Siklus 2

Belum tercapainya indicator keberhasilan untuk hasil belajar dikarenakan peserta didik masih kesulitan dalam memahami masalah dan menarik kesimpulan hasil diskusi kelompok. Selain itu, peserta didik masih belum teliti dalam membaca soal evaluasi dan salah dalam menterjemahkan kalimat/masalah pada soal.

\section{Siklus 3}

Perencaan III

Tahap perencanaan yang dilakukan pada siklus 3, yaitu menyusun perangkat pembelajaran berdasarkan hasil refleksi pada siklus 2 , dengan melengkapi hal-hal penting yang perlu ditambahkan dan diperhatikan.

Pelaksanaan III
Tahap pelaksanaan III dilakukan dalam satu pertemuan, yaitu hari Senin, 13 November 2020. Pada tahap apersepsi, guru menampilkan masalah dalam kontekstual berkaitan dengan persamaan garis lurus dengan menggunakan media powerpoint. Dari permasalahan tersebut, peserta didik berdiskusi secara kelompok untuk menemukan model matematika dari masalah kontekstual dan menggambarkannya dalam grafik persamaan garis lurus.

Setelah berdiskusi secara kelompok, perwakilan dari kelompok mempresentasikan hasil diskusi kelompok mereka. Setiap anggota kelompok yang presentasi bertanggung jawab untuk dapat menjawab atau menjelaskan jika ada pertanyaan dari kelompok lain. Kelompok yang tidak presentasi memperhatikan dan memberikan tanggapan terkait penyelesaian yang dipresentasikan.

Evaluasi pembelajaran dilakukan di luar jam pelajaran, dan dikerjakan melalui google form.

Pengamatan dan Evaluasi III

Pengamatan terhadap keaktifan peserta didik dalam mengikuti kegiatan pembelajaran dilakukan selama proses pembelajaran berlangsung. Peserta didik sudah mulai terbiasa untuk berdiskusi kelompok secara daring 
dengan menggunakan google meet. Setiap kelompok membagikan LKPD dalam bentuk google docs, yang bisa diisi oleh setiap anggota kelompok. Dalam diskusi kelompok, setiap anggota kelompok menyampaikan pendapatnya secara langsung maupun dengan menuliskan pendapatnya pada google docs yang telah dibagikan. Diskusi kelompok pada siklus 3 menjadi lebih aktif dan efektif. Sebagian besar anggota kelompok sudah aktif dalam mengikuti kegiatan diskusi kelompok. Selain berdiskusi dalam kelompok, beberapa kelompok menyampaikan pendapatnya dengan berdiskusi langsung dengan guru.

Refleksi III

Setelah dilakukan perhitungan hasil observasi, secara keseluruhan keaktifan peserta didik selama proses pembelajaran siklus 3 mengalami kenaikan jika dibandingkan dengan siklus 2, dimana skor rata-rata siklus 2 adalah 78 dan di siklus 3 menjadi 82, dengan kualifikasi/kategori keaktifan di siklus 3 adalah kategori tinggi. Sedangkan berdasarkan hasil angket, keaktifan peserta didik jika mengalami kenaikan dari siklus 2, dimana skor rata-rata siklus 2 adalah 78 dan di siklus 3 menjadi 82, dengan kualifikasi/ kategori tinggi. Sedangkan untuk hasil belajar, diperoleh nilai rata-rata 79.6 dimana terdapat 15 peserta didik yang tuntas, sedangkan 8 peserta didik tidak tuntas. Nilai rata-rata hasil belajar peserta didik sudah mengalami peningkatan dibandingkan siklus 1 dan siklus 2.

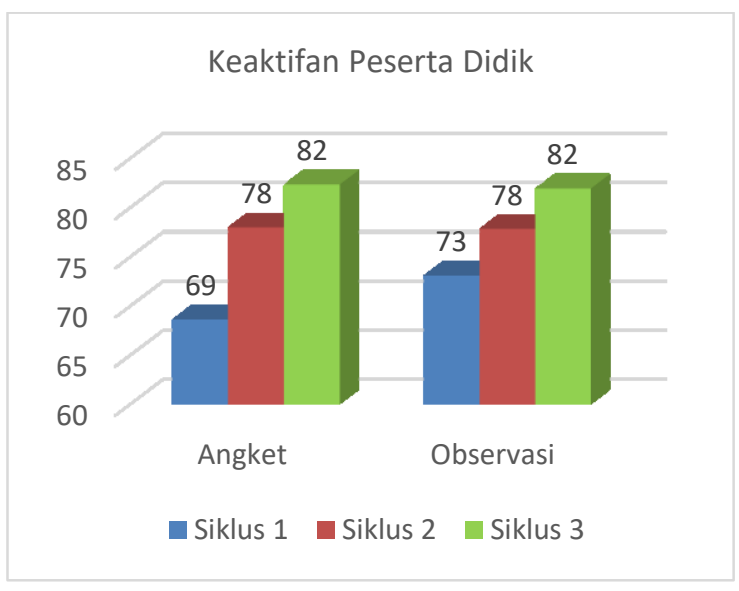

Gambar 3. Peningkatan Keaktifan

Peserta Didik

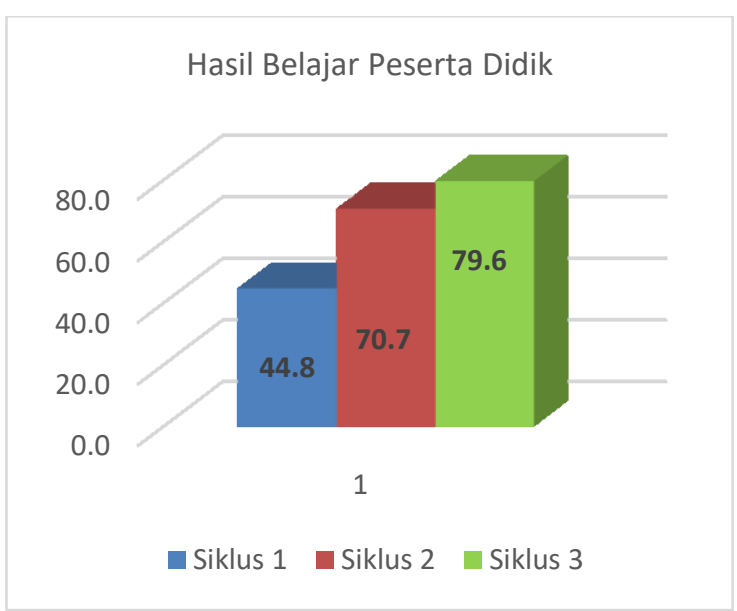

Gambar 3. Peningkatan Hasil Belajar Peserta Didik

\section{PENUTUP}

\section{Simpulan}

$$
\text { Implementasi pembelajaran }
$$
berbasis masalah dapat meningkatkan keaktifan dan hasil belajar peserta didik. Hal ini terlihat dari rata-rata nilai 
observasi dan angket keaktifan peserta didik yang mencapai nilai 82 , dengan kategori tinggi, dan rata-rata nilai hasil belajar yang mencapai 79,6. Melalui masalah kontekstual yang diberikan dalam diskusi kelompok, peserta didik lebih aktif dalam mengembangkan keterampilan berpikir kritis, menyelesaikan masalah dan mengembangkan pengetahuan. Dalam diskusi kelompok, peserta didik juga dilatih untuk berbagi pengetahuan yang mereka miliki dengan anggota kelompok yang lain.

\section{Saran}

Berdasarkan hasil penelitian
yang dilakukan, peneliti dapat mengemukakan saran, (1) bagi guru, pembelajaran problem based learning dengan dapat meningkatkan keaktifan peserta didik dalam mengikuti kegiatan pembelajaran, yang akan berdampak pada peningkatan hasil belajar, (2) bagi peneliti lain, dapat mengadakan penelitian lebih lanjut tentang tema lain dalam pembelajaran dan instrument keaktifan yang dibuat lebih spesifik.

\section{Ucapan Terimakasih}

Ucapan terimakasih yang sebesar-besarnya disampaikan kepada ibu Sri Suryanti, M.Si. selaku dosen pembimbing, ibu Dra. Masfufah selaku guru pamong, ibu I Gusti Ayu Putu
Intan Udayani, S.Pd., M.Si., selaku Kepala SMP Lentera Kasih Bali yang telah memberi tempat dan waktu pelaksanaan penelitian ini. Serta guruguru dan rekan sejawat yang telah mendukung terlaksananya penelitian ini.

\section{DAFTAR PUSTAKA}

Junaedi, Irwan. 2019. Pendalaman Materi Matematika Modul 1 Geometri KB 4 Pembelajaran Geometri. Jakarta: Kemendikbud. Khiriyah, Afifatul. 2015. Peningkatan Hasil Belajar dan Keaktifan Siswa pada Mata Pelajaran Keterampilan Komputer dan Pengelolaan Informasi (KKPI) Melalui Model Pembelajaran Problem Based Learning (PBL) Kelas XI TKJ di SMK Negeri Sine (Skripsi). Jogjakarta: Universitas Negeri Yogyakarta.

Sanjaya, Wina. 2011. Strategi Pembelajaran Berorientasi Standar Proses Pendidikan. Jakarta: Kencana Prenada Media.

Sanjaya, Wina. 2016. Penelitian Tindakan Kelas. Jakarta: Kencana Prenada Media.

Suryanti, S., Khikmiyah, F., Zawawi, I., \& Fauziyah, S. (2014). Peningkatan Penguasaan Konsep Matriks Melalui Model 
Pembelajaran Kooperatif Tipe Two

Stay Two Stray (Tsts).

DIDAKTIKA: Jurnal Pemikiran

Pendidikan, 21(1), 14-27.

Suryanti, S., Sutaji, D., \& Arifani, Y. (2019). Student 's engagement behaviour and their success in abstract algebra : structural equation modelling approach. In Journal of Physics: Conference Series, $\quad 1188, \quad 012105$. https://doi.org/10.1088/1742$6596 / 1188 / 1 / 012105$
Wulandari, Tutik. 2015. Peningkaran Keaktifan dan Hasil Belajar Matematika Melalui Model Pembelajaran Problem Based Learning (PTK pada Siswa Kelas VIIIG Semester Genap SMP Negeri 1 Kartasura Tahun Pelajaran 2014/2015) (Skripsi). Surakarta: Universitas Muhammadiyah Surakarta.

https://www.kajianpustaka.com/2019/0 3/penelitian-tindakan-kelasptk.html (diakses 12 Oktober 2020) 